\title{
Formulation and characterization of novel functional beverages with antioxidant and anti-acetylcholinesterase activities
}

\author{
Suree Nanasombat, Jidapa Thonglong, and Jutharat Jitlakha
}

Department of Biology, Faculty of Science, King Mongkut's Institute of Technology Ladkrabang, Bangkok 10520, Thailand

Corresponding author: Suree Nanasombat, $\mathrm{PhD}$, Associate Professor, Department of Biology, Faculty of Science, King Mongkut's Institute of Technology Ladkrabang, Bangkok 10520, Thailand

Submission date: October 27, 2014; Acceptance date: January 5, 2015; Publication date: January 7, 2015

\begin{abstract}
Background: Nowadays, there is increased consumer demand for high-antioxidant foods. Drinking high-antioxidant beverages may help to protect against aging, Alzheimer's disease, and other chronic diseases. Grapes and some plants including Phyllanthus emblica, Terminalia chebula, Kaempferia parviflora, Centella asiatica, Nelumbo nucifera, Rauvolfia serpentina, Ginkgo biloba, Crocus sativus, Clitoria ternatea and others are well-known to possess antioxidant, neuroprotective and other health-promoting activities. Thus, it is possible to use these plants for the development of new functional beverages.
\end{abstract}

Methods: Ten formulations of beverages were produced. The 5 non-alcoholic beverages contained dried medicinal plants, fresh grapes and others and are as follows: beverage B1: 10.2\% K. parviflora rhizomes, $5.1 \%$ brown sugar and $84.7 \%$ water; beverage B2: $0.45 \%$ Ardisia polycephala leaves, $0.45 \%$ C. asiatica leaves, $0.36 \%$ C. ternatea flowers, $0.45 \%$ C. sativus pollens, $0.45 \%$ G. biloba leaves, $0.45 \%$ Melodorum fruticosum flowers, $0.90 \%$ N. nucifera petals, $0.45 \%$ Nymphaea lotus petals, $5.43 \%$ crystalline sugar and $90.58 \%$ water; beverage B3: $0.62 \%$ A. polycephala fruits, $0.35 \%$ C. ternatea flowers, $0.44 \%$ G. biloba leaves, $2.64 \% \mathrm{~K}$. parviflora rhizomes, $1.76 \% \mathrm{P}$. emblica fruits, $0.88 \% \mathrm{~T}$. chebula fruits, $5.28 \%$ brown sugar and $88.03 \%$ water; beverage B4: $0.51 \%$ Acorus calamus stems, $0.68 \%$ C. ternatea flowers, $4.23 \%$ K. parviflora rhizomes, $0.85 \%$ N. nucifera petals, $0.85 \% \quad$ N. lotus petals, $0.85 \%$ M. fruticosum flowers, $0.34 \%$ R. serpentina roots, $0.34 \%$ U. gambir, $1.69 \%$ Zingiber officinale rhizomes, $5.08 \%$ brown sugar and $84.60 \%$ water; beverage B5: $53.09 \%$ fresh grapes, $2.65 \%$ brown sugar and $44.25 \%$ water. After heating, filtering, and cooling, these beverages were put in sterile bottles. One part of each beverage was stored at $4^{\circ} \mathrm{C}$ for 23 weeks before analyzing, but the other two parts were used to prepare the alcoholic beverage of each formulation. Grapes were mixed with the beverages B1, B2, B3, B4 and B5 in the ratio of 60:40 to prepare alcoholic beverages $\mathrm{W} 1, \mathrm{~W} 2, \mathrm{~W} 3, \mathrm{~W} 4$ and W5, respectively. Two different fermentation conditions (fermentation 
with or without pieces of sliced medicinal plant residue, PMPR) were compared. After fermenting, racking and aging, all alcoholic beverages, as well as all non-alcoholic beverages, were analyzed for some phytochemical properties.

Results: Grape fermented with PMPR had higher anti-acetylcholinesterase and antioxidant activities, and total phenolics, flavonoids and tannins, compared to the others. Among all nonalcoholic beverages, the beverage B3 contained the highest anti-acetylcholinesterase $(22.78 \%$ inhibition at 1:10,000 dilution) and antioxidant activities (reducing capacity, $4.22 \mathrm{mmol}$ $\mathrm{Fe}(\mathrm{II}) / 100 \mathrm{~mL}$ ), total phenolics, flavonoids, and tannins (494.44 $\mathrm{mg}$ gallic acid equivalents) (GAE)), $383.22 \mathrm{mg}$ catechin equivalents (CE) and $338.29 \mathrm{mg}$ tannic acid equivalents ((TAE)/100 mL, respectively). Among all alcoholic beverages, the beverage W3 (fermented with PMPR) exhibited the highest antioxidant activity (DPPH radical inhibition, $95.99 \mathrm{mg}$ trolox equivalents and reducing capacity, $3.57 \mathrm{mmol} F(\mathrm{II}) / 100 \mathrm{~mL}$ ), total phenolics, flavonoids and tannins (239.71 mg GAE, $372.67 \mathrm{mg} \mathrm{CE}$ and $157.67 \mathrm{mg}$ TAE/100 $\mathrm{mL}$, respectively). The beverage W2 (fermented with PMPR) had the highest anti-acetylcholinesterase activity $(21.35 \%$ inhibition at 1:10,000 dilution).

Conclusion: The beverages B3, W2 and W3 contained valuable sources of natural antioxidants and acetylcholinesterase inhibitors, and may provide health benefits when consumed.

Keywords: medicinal plant, wine, grape, anti-Alzheimer's disease, antioxidant

\section{BACKGROUND}

Nowadays, there are increasing consumer demands for foods which contain ingredients that may impart health benefit beyond basic nutrition. Beverages have been consumed habitually to deliver high concentrations of functional ingredients. They represent not only a suitable medium for the dissolution of functional components, but also a convenient method of consumption. Functional foods and beverages are products offering functional health benefits. In 2013, the global market for functional foods which make specific functional health claims was worth an estimated USD $\$ 43.27$ billion [1]. The global market of these food products continues to increase in size. It is expected to grow by $25 \%$ in 2017 , compared to the last available data from 2013 [2]. These functional foods are produced by adding appropriate quantities of substances that can provide health benefits beyond those furnished by traditional nutrients. There are a wide variety of functional beverage products, including sport and performance beverages, ready to drink teas, vitamin fortified water, soy beverages and other energy beverages [3]. The antioxidant rich beverage is one of the innovative products that should be considered to develop due to an increased demand for intake of dietary antioxidants with the hope to be healthy and free from diseases. As a result of increased education, there is increasing thought that certain nutrients and dietary composition with antioxidant properties may help to defend against oxidative stress and damage induced by free radicals in the body- thereby protecting against oxidative stress injury.

Reactive oxygen species, such as superoxide radical, hydroxyl radical, peroxynitrate, hydrogen peroxide and peroxyl radical are formed naturally within the biological system and are potentially able to create oxidative damage via interaction with bio-molecules. The free radicals 
are also produced by enzymatic reaction and by external sources, such as pollution, cigarette smoke, and sunlight [3,4]. There are some evidences which indicate that free radicals are associated with damage of surrounding cellular components, including proteins, lipids, carbohydrates, and DNA. This can lead to the changes of cellular structures and functions. When excessive free radicals are formed, cellular injury can occur, leading to a broad range of degenerative alterations, such as tissue degradation, cardiogenesis, aging, diabetes, neurodegenerative diseases and other oxidative stress related diseases [5].

Alzheimer's disease (AD), the most common cause of dementia in the elderly, is a neurodegenerative aged-related disease affecting major brain areas, including the cortex and limbic system. Cognitive, functional and behavioral dysfunction associated with AD may be caused by a consistent deficit in cholinergic neurotransmission. Neuropathologic studies revealed the neuronal loss in regions associated with memory and cognition, the accumulation of the abnormal protein deposits including senile neuritic plaques (extracellular accumulation of insoluble aggregates of $\beta$-amyloid protein) and neurofibrillary tangles (intraneuronal cortical structures consisting of tau protein aggregates), the reduction in activity of choline acetyltransferase (an enzyme responsible for acetylcholine synthesis) and neurotransmitter depletion (mainly acetylcholine) in the brains of AD patients [6-8]. Acetylcholinesterase, a serine-protease, hydrolyses the carboxylic ester of neurotransmitter acetylcholine to choline and acetic acid [9]. Thus, inhibition of acetylcholinesterase activity is a strategy for treatment of AD. This enzyme terminates nerve impulse transmission at the cholinergic synapses by rapid hydrolysis of acetylcholine. Enhancement of central cholinergic activity can be done by use of anti-cholinesterase inhibitors [6]. These inhibitors were found to enhance central cholinergic function by inhibiting enzymes that degrade acetylcholine- thus increasing availability of acetylcholine in the synaptic region and restoring deficient cholinergic neurotransmission [10]. However, synthetic drugs, such as tacrin, rivastigmine and donepezil used for treatment of AD have been reported to cause some side effects (nausea and vomiting) [11]. For these reasons, use of acetylcholinesterase inhibitors from plants may be a safer way for prevention or treatment of AD.

It is well documented that oxidative stress is involved in the pathogenesis of $A D$, as the mammalian brain is very sensitive to oxidative damage and the neural cells are more susceptible to the oxidative stress, (compared to other tissues) [5]. The antioxidant therapeutic potentials for AD have been reported [12]. Thus, consumption of foods made from fruits, vegetables and medicinal plants rich in natural antioxidants, such as polyphenols, (which increase cell resistance to oxidative stress), may be helpful to protect against the oxidative stress related diseases including $\mathrm{AD}$ or improve cognitive performance in humans. Grapes (Vitis vinifera), commonly used for wine production, are known to be one of the major sources of flavonoids, including anthocyanin, flavanols and resveratrol [13]. Antioxidant and neuroprotective activities, and other health-promoting properties of the active compounds in grapes were reported [14]. Moreover, researchers have demonstrated that some plants including Phyllanthus emblica (Indian gooseberry) fruits [15-17], Terminalia chebula (myrabolan wood) fruits [17, 18], Uncaria gambir (gambir) [17-19], and other plants which possess strong antioxidant activity contained high amount of phenolics and flavonoids. In addition, some plants with strong acetylcholinesterase inhibitory activity were Kaempferia parviflora (black galingale) rhizomes, 
Centella asiatica (asiatic pennywort) leaves, Nelumbo nucifera (sacred lotus) petals, Rauvolfia serpentina root (serpentine root) [17]. Ginkgo biloba (gingko) leaves and Crocus sativus (saffron) pollen are also well-known as cognitive enhancers that have been used to treat disorders of the nervous system [20]. Therefore, it is possible to use these plants as ingredients for development of new non-alcoholic and alcoholic functional beverages with high antioxidant and anti-acetylcholinesterase activities for prevention of AD and other related chronic diseases.

\section{METHODS}

\section{Plant materials}

Fresh grapes (Vitis vinifera L., fruits) and dried plants of black galingale (Kaempferia parviflora, rhizomes), gambir (Uncaria gambir (Hunter) Roxb.), asiatic pennywort (Centella asiatica (L.) Urban., whole plants), white lotus (Nymphaea lotus Linn., petals), sacred lotus (Nelumbo nucifera Gaertn., petals), gingko (Ginkgo biloba L., leaves), philangkasa (Ardisia polycephala Wall, leaves and fruits), Indian gooseberry (Phyllanthus emblica Linn., fruits), lumduan (Melodorum fruticosum Lour., flowers), myrabolan wood (Terminalia chebula Retz, fruits), saffron (Crocus sativus L., pollens), blue pea (Clitoria ternatea L., flowers), ginger (Zingiber officinale Roscoe., rhizomes), serpentine root (Rauvolfia serpentina (L.) Benth., roots), mytle grass (Acorus calamus Linn, stems) were purchased in Bangkok, Thailand.

\section{Non-alcoholic beverage preparation}

Five formulations of non-alcoholic beverages were produced. The non-alcoholic beverages consisted of dried medicinal plants, fresh grapes and other ingredients as listed in Table 1.

Table 1. Beverage composition of non-alcoholic beverages

\begin{tabular}{ll}
\hline Sample code & Beverage composition \\
\hline B1 & $10.2 \%$ black galingale rhizomes, $5.1 \%$ brown sugar and $84.7 \%$ water \\
B2 & $0.45 \%$ philangkasa leaves, $0.45 \%$ asiatic pennywort, $0.36 \%$ blue pea flowers, \\
& $0.45 \%$ saffron pollens, $0.45 \%$ gingko leaves, $0.45 \%$ lumduan flowers, $0.90 \%$ sacred \\
& lotus petals, $0.45 \%$ white lotus petals, $5.43 \%$ crystalline sugar and $90.58 \%$ water \\
B3 & $0.62 \%$ philangkasa fruits, $0.35 \%$ blue pea flowers, $0.44 \%$ gingko leaves, $2.64 \%$ \\
& black galingale rhizomes, $1.76 \%$ Indian gooseberry fruits, $0.88 \%$ myrabolan wood \\
& fruits, $5.28 \%$ brown sugar and $88.03 \%$ water \\
B4 & $0.51 \%$ mytle grass stems, $0.68 \%$ blue pea flowers, $4.23 \%$ black galingale rhizomes, \\
& $0.85 \%$ sacred lotus petals, $0.85 \%$ white lotus petals, $0.85 \%$ lumduan flowers, \\
& $0.34 \%$ serpentine roots, $0.34 \%$ gambir, $1.69 \%$ ginger rhizomes, $5.08 \%$ brown \\
& sugar and $84.60 \%$ water \\
& $53.09 \%$ fresh grape without seed, $2.65 \%$ brown sugar and $44.25 \%$ water \\
\hline
\end{tabular}

All dried medicinal plants were coarsely ground. Fresh grapes were washed and destemmed, and all seeds were removed. Then, the grapes were crushed and homogenized to uniform slurry. All ingredients of each formulation were mixed and boiled in $1.5 \mathrm{~L}$ water for $20 \mathrm{~min}$. In each formulation, the infusion of the ingredient mixture obtained after filtering through cheese cloth was evenly divided into 3 parts, and the pieces of medicinal plant residue (PMPR) left after 
filtering were kept for alcoholic beverage preparation. After cooling, 1 in the 3 parts of each nonalcoholic beverage was filled in sterile dark green bottles and stored at $4{ }^{\circ} \mathrm{C}$ for 23 weeks, and the other 2 parts were immediately used for alcoholic beverage preparation in the next step. All formulations of non-alcoholic beverages were determined for their antioxidant and antiacetylcholinesterase activities, total phenolic, flavonoid, and tannin contents, and $\mathrm{pH}$ and color values.

\section{Alcoholic beverage preparation}

To prepare the fermenting must, grapes without seeds were crushed and homogenized to uniform slurry. The pulp slurry of grapes was mixed with each formulation of non-alcoholic beverages (beverages B1, B2, B3, B4 and B5) in a 60:40 ratio of grape pulp slurry to each formulation of the beverages (for production of alcoholic beverages W1, W2, W3, W4 and W5, respectively), in a 1L sterile Erlenmeyer flask. In each formulation, two different fermenting musts (grape pulp slurry mixed with or without PMPR) were prepared for 2 different fermentation conditions. Diammonium phosphate $(0.03 \%)$ was added into each fermenting must. The total soluble sugar content and $\mathrm{pH}$ value of each fermenting must were adjusted to $24^{\circ} \mathrm{Brix}$ and $\mathrm{pH} 5.5 \mathrm{using}$ sucrose and citric acid, respectively. Then, all fermenting musts were subjected to heat treatment at $80^{\circ} \mathrm{C}$ for $5 \mathrm{~min}$, and a cool down to $30^{\circ} \mathrm{C}$. After inoculation of $5 \%$ yeast starter culture (Saccharomyces cerevisiae TISTR 5109), the fermentation process was carried out under an identical condition for 2 weeks at $30^{\circ} \mathrm{C}$. At the end of fermentation, the fermented broth was filtered, pasteurized at $80^{\circ} \mathrm{C}$ for $5 \mathrm{~min}$, cooled and filled in the sterile dark green bottles. Then, all bottles containing an alcoholic beverage were stored at $4^{\circ} \mathrm{C}$ for 2 weeks for aging process, then racked and continued aging for 19 weeks at $4^{\circ} \mathrm{C}$. All alcoholic beverage samples as well as the Italian red wine (a good red wine 2011, purchased at the central market, Florence, Italy, a positive control) were analyzed for their antioxidant and anti-acetylholinesterase activities, total phenolic, flavonoid and tannin contents, total acidity, $\mathrm{pH}$ and color values.

\section{Analysis of grapes, grape extract and all beverages}

Fresh grapes were used for beverage production, and all beverage samples were determined for their $\mathrm{pH}$ value and total acidity according to the method of AOAC [21]. Then, the fresh grapes were extracted according to the method as described by Orak [22]. The crude methanolic extract of grapes was analyzed for their antioxidant and anti-acetylcholinesterase activities, and total phenolic, tannin and flavonoid contents.

\section{Determination of antioxidant activity}

DPPH radical scavenging activity assay: The DPPH radical scavenging activity was determined according to the method as described by Costa et al. [23], with some modification. The sample (120 $\mu \mathrm{L}$ of $1: 10$ dilution of beverage sample or $120 \mu \mathrm{L}$ of $1 \mathrm{mg} / \mathrm{mL}$ grape extract in $30 \%$ methanol) was mixed with $2.8 \mathrm{~mL}$ of $0.1 \mathrm{mM}$ DPPH (2,2-diphenyl-1-picrylhydrazyl, Fluka, Sigma-Aldrich, Germany) in methanol. After incubation for $30 \mathrm{~min}$ in the dark at room temperature, the absorbance was measured at $517 \mathrm{~nm}$ against blank (methanol). A standard curve of trolox at $1.563-25.000 \mu \mathrm{g} / \mathrm{mL}$ concentration was prepared. The results were expressed as 
milligrams of trolox equivalents (TE) per $100 \mathrm{~mL}$ beverage or per gram extract \pm standard deviation (SD) for triplicate results of analysis. The $\alpha$-tocopherol was analyzed as a positive control.

Ferric reducing antioxidant power (FRAP) assay: Antioxidant activity of each sample was determined according to the method previously described by Martins et al. [24]. Briefly, the sample $(100 \mu \mathrm{L}$ of 1:10 dilution of beverage sample or $100 \mu \mathrm{L}$ of $1 \mathrm{mg} / \mathrm{mL}$ grape extract in $30 \%$ methanol) was mixed with $3.0 \mathrm{~mL}$ FRAP reagent $(25 \mathrm{~mL}$ of $300 \mathrm{mM}$ acetate buffer, $2.5 \mathrm{~mL}$ of $10 \mathrm{mM}$ TPTZ ((2,4,6-tri-2-pyridyl-s-triazine, Fluka, Sigma-Aldrich, Switzerland) in $40 \mathrm{mM} \mathrm{HCl}$ and $2.5 \mathrm{~mL}$ of $\left.20 \mathrm{mM} \mathrm{FeCl}{ }_{3} \cdot 6 \mathrm{H}_{2} \mathrm{O}\right)$ ) in a test tube with stopper, and this mixture was incubated at $37^{\circ} \mathrm{C}$ for $30 \mathrm{~min}$. The absorbance was measured at $595 \mathrm{~nm}$ using UV-visible spectrophotometer ((UV1601, Shimadzu Scientific Instruments (Oceania) Pty. Ltd., Australia)) against blank (FRAP reagent without the sample). The concentration of $\mathrm{Fe}^{2+}$-TPTZ (reducing capacity) was calculated by comparing the absorbance at $595 \mathrm{~nm}$ with the standard curve of the Fe (II) standard solutions (ferrous sulfate heptahydrate) at a 0.047-3.000 mM concentration. The results were expressed as the mean $\left(\mathrm{mmol}\right.$ of $\mathrm{Fe}^{2+}$ per $100 \mathrm{~mL}$ beverage or per gram extract) \pm SD for triplicate results of analysis. The $\alpha$-tocopherol was analyzed as a positive control.

\section{Acetylcholinesterase inhibitory activity assay}

The anti-acetylcholinesterase activity of each sample was determined according to the method previously reported by Ellman et al. [25] and Sancheti et al. [26] with a slight modification. Acetylcholinesterase from electric eel (E.C. 3.1.1.7, Sigma, Sigma-Aldrich, USA), acetylcholine iodide (ATCI, Fluka, Sigma-Aldrich, United Kingdom), 5, 5'-dithio-bis (2-nitrobenzoic acid) (DTNB, Sigma, Sigma-Aldrich, USA) were employed. Galanthamine hydrobromide from Lycoris sp. (Sigma, Sigma-Aldrich, USA) was used as the standard drug. In this method, $240 \mu \mathrm{L}$ acetylcholinesterase solution $(0.025 \mathrm{U} / \mathrm{mL}), 120 \mu \mathrm{L}$ sample $(120 \mu \mathrm{L}$ of 1:10000 diluted beverage sample or $120 \mu \mathrm{L}$ of 0.1 and $1 \mathrm{mg} / \mathrm{mL}$ of grape extract in $30 \%$ methanol), 2,160 $\mu \mathrm{L}$ Tris-HCl buffer $(50 \mathrm{mM}$ Tris- $\mathrm{HCl}, \mathrm{pH} 8)$ were mixed and incubated at $4{ }^{\circ} \mathrm{C}$ for $30 \mathrm{~min}$. Then, $240 \mu \mathrm{L}$ DTNB $(0.3 \mathrm{mM})$ and $240 \mu \mathrm{L}$ ATCI $(1.8 \mathrm{mM})$ were added. The reaction mixture was incubated at $37{ }^{\circ} \mathrm{C}$ for $20 \mathrm{~min}$. Then, the absorbance was measured at $412 \mathrm{~nm}$ using UV-visible spectrophotometer ((UV1601, Shimadzu Scientific Instruments (Oceania) Pty. Ltd., Australia)). The blank was prepared for correcting the background absorbance, in which the acetylcholinesterase enzyme was replaced by the buffer. Control was performed in the same manner by replacing the sample with $30 \%$ methanol. The percentage of inhibition was calculated using the following formula:

$$
\% \text { inhibition }=100 \times\left(\mathrm{A}_{\text {Control }}-\mathrm{A}_{\text {Sample }}\right) / \mathrm{A}_{\text {Control }}
$$

where $\mathrm{A}_{\mathrm{Control}}$ and $\mathrm{A}_{\text {Sample }}$ are the absorbance values of the control and the sample, respectively.

\section{Determination of total phenolic content}

Total phenolic content of each sample was determined according to the method as described by Singleton et al. [27]. Each sample $(100 \mu \mathrm{L}$ of 1:10 dilution of beverage sample or $100 \mu \mathrm{L}$ of 1 
$\mathrm{mg} / \mathrm{mL}$ grape extract in 30\% methanol) was transferred to a test tube and then $6 \mathrm{~mL}$ ultra-pure water was added. Folin-Ciocalteu's phenol reagent (Fluka, Sigma-Aldrich, Switzerland) (500 $\mu \mathrm{L}$ ) was added, shaken thoroughly, and allowed to stand for $1 \mathrm{~min}$. Then, $1.5 \mathrm{~mL}$ of $20 \%$ $\mathrm{Na}_{2} \mathrm{CO}_{3}$ and $1.9 \mathrm{~mL}$ of ultra-pure water were added. After incubation for $30 \mathrm{~min}$ at $25^{\circ} \mathrm{C}$, the absorbance was measured at $760 \mathrm{~nm}$ using UV-visible spectrophotometer ((UV1601, Shimadzu Scientific Instruments (Oceania) Pty. Ltd., Australia)). A standard curve of gallic acid (Fluka, Sigma-Aldrich, Spain) at a $10-1,000 \mu \mathrm{g} / \mathrm{mL}$ concentration was prepared using the similar procedure. The results were expressed as the mean ((milligrams of gallic acid equivalents (GAE) per $100 \mathrm{~mL}$ of beverage or per gram extract)) \pm SD for triplicate results of analysis.

\section{Determination of total flavonoid content}

Total flavonoid content of each sample was analyzed according to the method as described by Yang et al. [28]. The sample $(250 \mu \mathrm{L}$ of $1: 10$ dilution of a beverage sample or $250 \mu \mathrm{L}$ of 1 $\mathrm{mg} / \mathrm{mL}$ grape extract in $30 \%$ methanol) was mixed with $1.25 \mathrm{~mL}$ distilled water and $75 \mu \mathrm{L}$ of $5 \% \mathrm{NaNO}_{2}(\mathrm{w} / \mathrm{w})$. After $5 \mathrm{~min}, 150 \mu \mathrm{L}$ of $10 \% \mathrm{AlCl}_{3}(\mathrm{w} / \mathrm{w})$ was added and allowed to react for 6 min. Then, $500 \mu \mathrm{L}$ of $1 \mathrm{M} \mathrm{NaOH}$ was added. The final volume was adjusted to $3 \mathrm{~mL}$ with distilled water. The mixture was mixed well and the absorbance was immediately measured at $510 \mathrm{~nm}$ against the blank using UV-visible spectrophotometer ((UV1601, Shimadzu Scientific Instruments (Oceania) Pty. Ltd., Australia)). Catechin (10-750 $\mu \mathrm{g} / \mathrm{mL})$ was used to plot a standard curve. Total flavonoid contents in all samples were expressed as the mean ((milligrams of catechin eqivalents (CE) per $100 \mathrm{~mL}$ of beverage or per gram extract)) \pm SD for triplicate results of analysis.

\section{Determination of total tannin content}

Total tannin content of each sample was determined using the Folin-Denis method [29]. The sample $(50 \mu \mathrm{L}$ of $1: 10$ dilution of beverage sample or $50 \mu \mathrm{L}$ of $1 \mathrm{mg} / \mathrm{mL}$ grape extract in $30 \%$ methanol) was transferred to a test tube and the volume was adjusted to $7.5 \mathrm{~mL}$ with distilled water. Then, $0.5 \mathrm{~mL}$ of Folin-Denis reagent (Fluka, Switzerland) and $1 \mathrm{~mL}$ of $35 \% \mathrm{Na}_{2} \mathrm{CO}_{3}$ were added to the mixture and mixed well. The total volume was adjusted to $10 \mathrm{~mL}$ with distilled water. After well mixing, the absorbance was measured at $700 \mathrm{~nm}$ using UV-visible spectrophotometer ((UV1601, Shimadzu Scientific Instruments (Oceania) Pty. Ltd., Australia)). Tannic acid (10-1,000 $\mu \mathrm{g} / \mathrm{mL})$ was used to plot a standard curve. Total tannin contents in all samples were expressed as the mean ((milligrams of tannic acid equivalents (TAE) per $100 \mathrm{~mL}$ beverage or per gram extract)) $\pm \mathrm{SD}$ for triplicate results of analysis.

\section{Color measurements}

The color values of all beverage samples were measured using a colorimeter (Minolta Chroma Meter CR-300). To do color measurement, the center of the white calibration plate was measured when performing calibration. The beverage sample $(10 \mathrm{~mL})$ was then filled in the no. 3 glass container. Then, this container was placed on the tip of the measuring head flat before pressing the head's measuring botton. Three measurements were automatically taken for better accuracy. Absolute measurement was displayed as $\mathrm{L}^{*} \mathrm{~b}^{*} \mathrm{a}^{*}$. The CIE L*, a*, b* color parameters were 
recorded as $\mathrm{L}^{*}$, brightness $\left(100=\right.$ white, $0=$ black); $\mathrm{a}^{*}$ (positive $=$ redness, negative $=$ greenness $) ; b^{*}$ (positive $=$ yellowness, negative $=$ blueness $)$ values .

\section{RESULTS}

\section{The pH value and total acidity of the beverages}

Among all the non-alcoholic beverages, the beverage B1 had the highest $\mathrm{pH}$ (5.47) and lowest total acidity $(0.08 \%)$, while the beverage $\mathrm{B} 3$ had the lowest $\mathrm{pH}(3.44)$ and highest total acidity $(0.48 \%)$. Compared to the $\mathrm{pH}$ values of the non-alcoholic beverages, the $\mathrm{pH}$ values of alcoholic beverages which contained grape were lower. The $\mathrm{pH}$ values of alcoholic beverages produced varied from 3.58 to 3.93 , whereas the total acidity varied from $0.45 \%$ to $0.68 \%$. The beverages W3 and W5 had lower pH values (3.58-3.64) than other alcoholic beverage formulations. However, the beverages W2 and W3 had the highest total acidity (0.60-0.68\%) (Table 2).

Table 2. The $\mathrm{pH}$ value, total acidity and color value of non-alcoholic and alcoholic functional beverages

\begin{tabular}{|c|c|c|c|c|c|c|}
\hline Beverages & $\mathbf{p H}^{\mathrm{A}} \pm \mathrm{SD}$ & $\begin{array}{l}\text { Total acidity } \\
\text { ( g tartaric acid/ } \\
100 \mathrm{~mL}) \pm \text { D }\end{array}$ & $\mathbf{L}^{*} \pm \mathbf{S D}$ & $a^{*} \pm$ SD & $\mathbf{b}^{*} \pm \mathrm{SD}$ & Color \\
\hline \multicolumn{7}{|c|}{ Non-alcoholic beverages } \\
\hline $\mathrm{B}_{1}$ & $5.47^{\mathrm{a}^{*}} \pm 0.01$ & $0.08^{\mathrm{d}} \pm 0.00$ & $14.66^{\mathrm{d}} \pm 0.45$ & $10.15^{\mathrm{c}} \pm 0.21$ & $-4.84^{c} \pm 0.04$ & Red brown \\
\hline $\mathrm{B}_{2}$ & $4.10^{c} \pm 0.01$ & $0.45^{\mathrm{a}} \pm 0.00$ & $15.60^{\mathrm{c}} \pm 0.04$ & $11.86^{\mathrm{a}} \pm 0.09$ & $-5.17^{\mathrm{d}} \pm 0.03$ & Dark brown \\
\hline $\mathrm{B}_{3}$ & $3.44^{\mathrm{e}} \pm 0.01$ & $0.48^{\mathrm{a}} \pm 0.04$ & $18.44^{b} \pm 0.58$ & $12.04^{\mathrm{c}} \pm 0.16$ & $-2.45^{\mathrm{b}} \pm 0.12$ & $\begin{array}{l}\text { Very dark } \\
\text { brown }\end{array}$ \\
\hline $\mathrm{B}_{4}$ & $4.45^{\mathrm{b}} \pm 0.01$ & $0.23^{c} \pm 0.00$ & $12.34^{\mathrm{e}} \pm 0.17$ & $11.45^{\mathrm{b}} \pm 0.20$ & $-6.38^{\mathrm{e}} \pm 0.06$ & Light brown \\
\hline $\mathrm{B}_{5}$ & $3.61^{\mathrm{d}} \pm 0.01$ & $0.30^{\mathrm{b}} \pm 0.00$ & $30.61^{\mathrm{e}} \pm 0.03$ & $5.53^{\mathrm{d}} \pm 0.16$ & $-1.40^{\mathrm{a}} \pm 0.01$ & Light pink \\
\hline \multicolumn{7}{|c|}{ Alcoholic beverages fortified with medicinal plants } \\
\hline W1 (with PMPR ${ }^{\mathrm{B}}$ ) & $3.91^{\mathrm{b}} \pm 0.01$ & $0.45^{\mathrm{c}} \pm 0.00$ & $12.64^{\mathrm{f}} \pm 0.01$ & $13.43^{c} \pm 0.19$ & $-6.39^{f} \pm 0.02$ & Red violet \\
\hline W1 (without PMPR) & $3.73^{\mathrm{e}} \pm 0.01$ & $0.43^{c} \pm 0.04$ & $11.88^{\mathrm{g}} \pm 0.03$ & $16.58^{\mathrm{a}} \pm 0.64$ & $-4.83^{b} \pm 0.04$ & Red violet \\
\hline W2 (with PMPR) & $3.80^{c} \pm 0.01$ & $0.68^{\mathrm{a}} \pm 0.00$ & $10.48^{\mathrm{i}} \pm 0.05$ & $15.01^{\mathrm{b}} \pm 0.49$ & $-7.44^{\mathrm{i}} \pm 0.06$ & Blue violet \\
\hline W2 (without PMPR) & $3.74^{\mathrm{e}} \pm 0.01$ & $0.68^{\mathrm{a}} \pm 0.00$ & $10.71^{\mathrm{h}} \pm 0.04$ & $14.98^{\mathrm{b}} \pm 0.03$ & $-6.89^{h} \pm 0.02$ & $\begin{array}{l}\text { Light blue } \\
\text { violet }\end{array}$ \\
\hline W3 (with PMPR) & $3.61^{\mathrm{g}} \pm 0.01$ & $0.68^{\mathrm{a}} \pm 0.00$ & $14.76^{\mathrm{c}} \pm 0.06$ & $12.13^{\mathrm{d}} \pm 0.52$ & $-6.33^{\mathrm{e}} \pm 0.03$ & $\begin{array}{l}\text { Dark brown } \\
\text { violet }\end{array}$ \\
\hline W3 (without PMPR) & $3.64^{\mathrm{f}} \pm 0.01$ & $0.60^{\mathrm{b}} \pm 0.00$ & $15.82^{\mathrm{b}} \pm 0.04$ & $11.88^{\mathrm{d}} \pm 0.66$ & $-6.00^{\mathrm{d}} \pm 0.03$ & $\begin{array}{l}\text { Light brown } \\
\text { violet }\end{array}$ \\
\hline W4 (with PMPR) & $3.93^{\mathrm{a}} \pm 0.01$ & $0.45^{\mathrm{c}} \pm 0.00$ & $13.71^{\mathrm{e}} \pm 0.02$ & $12.13^{\mathrm{d}} \pm 0.23$ & $-6.53^{\mathrm{g}} \pm 0.04$ & $\begin{array}{l}\text { Dark brown } \\
\text { violet }\end{array}$ \\
\hline W4 (without PMPR) & $3.78^{\mathrm{d}} \pm 0.01$ & $0.45^{\mathrm{c}} \pm 0.00$ & $14.45^{\mathrm{d}} \pm 0.03$ & $11.84^{\mathrm{d}} \pm 0.78$ & $-5.08^{c} \pm 0.03$ & $\begin{array}{l}\text { Light brown } \\
\text { violet }\end{array}$ \\
\hline W5 & $3.58^{\mathrm{h}} \pm 0.01$ & $0.45^{\mathrm{c}} \pm 0.00$ & $19.48^{\mathrm{a}} \pm 0.01$ & $9.59^{\mathrm{e}} \pm 0.43$ & $-3.76^{a} \pm 0.01$ & Light pink \\
\hline Italian red wine & $2.95 \pm 0.01$ & $0.60 \pm 0.00$ & $9.99 \pm 0.03$ & $13.79 \pm 0.99$ & $-7.25 \pm 0.01$ & $\begin{array}{l}\text { Dark red } \\
\text { violet }\end{array}$ \\
\hline
\end{tabular}


The fresh grape used as a raw material had the $\mathrm{pH}$ value of 3.97 and contained $0.37 \%$ total acidity, calculated as tartaric acid. The Italian red wine had the lowest $\mathrm{pH}$ value (2.95) and had a total acidity of $0.6 \%$.

\section{Color value of the beverages}

$\mathrm{L}^{*}$ color value (brightness) of the beverage B5 was the highest ( $\mathrm{L}^{*}, 30.61$ ), among all nonalcoholic beverages $(\mathrm{P}<0.05)$. Similarly, the beverage W5 (grape alcoholic beverage) had the highest brightness $\left(\mathrm{L}^{*}, 19.48\right)$, among all alcoholic beverages. All formulations of alcoholic beverages fermented without PMPR had significantly higher $\mathrm{L}^{*}$ values than those of the same formulation fermented with PMPR $(\mathrm{P}<0.05)$. On the other hand, almost all alcoholic beverages fermented with PMPR had higher $\mathrm{a}^{*}$ (redness) and $\mathrm{b}^{*}$ (blueness) values. The $\mathrm{a}^{*}$ value of all samples varied from 5.53 to 16.58 , while the $b^{*}$ values varied from -1.4 to -7.44 . However, the Italian red wine showed the lowest brightness ( $\left.\mathrm{L}^{*}, 9.99\right)$, but relatively high redness $\left(\mathrm{a}^{*}, 13.79\right)$ and blueness $\left(b^{*},-7.25\right)$ (Table 2).

\section{Total phenolics, flavonoids and tannins in the beverages}

Among all formulations of non-alcoholic beverages, the beverage B3 contained the highest total phenolic, flavonoid and tannin contents (494.44 mg GAE, $383.22 \mathrm{mg}$ CE and 338.29 mg TAE / $100 \mathrm{~mL}$ beverage, respectively), followed by the beverages B4, B2, B1 and B5. For alcoholic beverages, the beverage W3 fermented with PMPR contained the highest amount of phenolics, flavonoids and tannins (239.71 mg GAE, $372.67 \mathrm{mg} \mathrm{CE}$ and $157.67 \mathrm{mg}$ TAE/ $100 \mathrm{~mL}$ beverage, respectively) among all formulations, followed by the beverages W4, W2, W1 and W5 (Table 3). In all beverage formulations, the fermentation with PMPR resulted in significantly higher phenolics, flavonoids and tannins as compared to those fermented without PMPR $(\mathrm{P}<0.05)$. The Italian red wine had higher total phenolics, flavonoids, but lower tannin contents $(332.72 \mathrm{mg}$ GAE, $376.56 \mathrm{mg}$ CE and $41.4 \mathrm{mg}$ TAE/ $100 \mathrm{~mL}$ beverage, respectively) as compared to W1-W5 alcoholic beverages. In case of grape extract, it contained total phenolics, flavonoids and tannins of $5.97 \mathrm{mg}$ GAE, $201.00 \mathrm{mg} \mathrm{CE}$ and $55.35 \mathrm{mg}$ TAE / g extract, respectively (Table 3).

\section{Antioxidant activity of the beverages}

Almost all the non-alcoholic beverages, except for the beverage B1 ( $K$. parviflora rhizome containing beverage), displayed significantly higher scavenging activity against DPPH radical than the beverage B5 (grape beverage) $(\mathrm{P}<0.05)$. Compared to the beverages B1 and B5, the beverages with mixed medicinal plants (beverages B2, B3 and B4) had stronger DPPH radical scavenging activity and ferric reducing capacity (Table 3). However, the beverages B3 and B4 displayed higher antioxidant activity than the beverage B2. In all formulations of the alcoholic beverages, fermentation of grape with PMPR displayed significantly stronger DPPH radical scavenging activity and ferric reducing capacity, compared to the fermentation without PMPR. Among all beverages, the beverage W3 fermented with PMPR showed the strongest antioxidant activity $(95.99 \mathrm{mg}$ trolox/ $100 \mathrm{~mL}$ beverage by DPPH method; antioxidant power of $3.57 \mathrm{mmol}$ $\mathrm{Fe}(\mathrm{II}) / 100 \mathrm{~mL}$ beverage by FRAP method) which was slightly stronger than the antioxidant activity of the Italian red wine $(87.23 \mathrm{mg}$ trolox/ $100 \mathrm{~mL}$ beverage; $3.43 \mathrm{mmol} \mathrm{Fe}$ (II)/100 mL beverage). The $\alpha$-tocopherol, a positive control, was the best DPPH radical quencher $(98.34 \pm$ 
$0.06 \mathrm{mg}$ trolox $/ \mathrm{g}$ ), but had the antioxidant power of $0.36 \mathrm{mmol} \mathrm{Fe}$ (II)/g). However, grape extract did not have a high antioxidant activity $(2.02 \mathrm{mg}$ trolox and $0.01 \mathrm{mmol} \mathrm{Fe}$ (II)/ $\mathrm{g}$ extract of fresh grape).

Table 3. Phytochemical properties of non-alcoholic and alcoholic functional beverages

\begin{tabular}{|c|c|c|c|c|c|c|}
\hline \multirow[t]{2}{*}{ Beverages } & \multirow{2}{*}{$\begin{array}{l}\text { Acetylcho- } \\
\text { linesterase } \\
\text { inhibition }^{\mathrm{A}} \\
(\%) \pm \mathrm{SD}\end{array}$} & \multirow[b]{2}{*}{$\begin{array}{l}\text { Total } \\
\text { Phenolics (mg } \\
\text { GAE/100 mL } \\
\text { beverages) } \pm \\
\text { SD }\end{array}$} & \multirow{2}{*}{$\begin{array}{l}\text { Total Flavonoids } \\
\text { (mg CE/100 mL } \\
\text { beverages) } \pm \mathrm{SD}\end{array}$} & \multirow{2}{*}{$\begin{array}{l}\text { Total Tannins } \\
\text { (mg TAE/100 } \\
\text { mL beverages) } \\
\pm \mathrm{SD}\end{array}$} & \multicolumn{2}{|c|}{ Antioxidant activity } \\
\hline & & & & & $\begin{array}{l}\text { DPPH assay } \\
\text { (mg trolox/100 } \\
\text { mL beverages) } \\
\pm \mathrm{SD}\end{array}$ & $\begin{array}{l}\text { FRAP assay } \\
\text { (mmol Fe(II)/100 } \\
\text { mL beverages) } \\
\quad \pm \text { SD }\end{array}$ \\
\hline \multicolumn{7}{|c|}{ Non-alcoholic beverages } \\
\hline B1 & $19.34^{\mathrm{b}^{*}} \pm 1.09$ & $50.82^{\mathrm{d}} \pm 0.71$ & $237.11^{\mathrm{d}} \pm 1.92$ & $56.12^{c} \pm 3.55$ & $13.22^{c} \pm 0.66$ & $0.33^{\mathrm{d}} \pm 0.02$ \\
\hline B2 & $14.71^{\mathrm{d}} \pm 1.09$ & $262.76^{\mathrm{c}} \pm 2.57$ & $314.33^{\mathrm{c}} \pm 2.89$ & $257.67^{\mathrm{b}} \pm 2.33$ & $91.19^{\mathrm{b}} \pm 0.45$ & $2.51^{\mathrm{c}} \pm 0.01$ \\
\hline B3 & $22.78^{a} \pm 0.94$ & $494.44^{\mathrm{a}} \pm 2.47$ & $383.22^{\mathrm{a}} \pm 2.55$ & $338.29^{\mathrm{a}} \pm 3.55$ & $91.95^{\mathrm{b}} \pm 0.23$ & $4.22^{\mathrm{a}} \pm 0.00$ \\
\hline B4 & $22.54^{\mathrm{a}} \pm 0.74$ & $330.25^{\mathrm{b}} \pm 2.47$ & $375.44^{\mathrm{b}} \pm 3.85$ & $261.55^{\mathrm{b}} \pm 3.55$ & $93.25^{\mathrm{a}} \pm 0.17$ & $3.39^{\mathrm{b}} \pm 0.01$ \\
\hline B5 & $17.44^{\mathrm{c}} \pm 0.62$ & $31.89^{\mathrm{e}} \pm 1.89$ & $207.67^{\mathrm{e}} \pm 1.67$ & $45.27^{\mathrm{d}} \pm 3.55$ & $15.62^{\mathrm{c}} \pm 0.54$ & $0.28^{\mathrm{e}} \pm 0.01$ \\
\hline \multicolumn{7}{|c|}{ Alcoholic beverages fortified with medicinal plants } \\
\hline $\begin{array}{l}\text { W1 (with } \\
\text { PMPR }^{\text {B }} \text { ) }\end{array}$ & $18.15^{\mathrm{e}} \pm 0.71$ & $61.11^{\mathrm{g}} \pm 1.23$ & $285.44^{\mathrm{e}} \pm 0.96$ & $52.25^{\mathrm{g}} \pm 3.55$ & $22.04^{\mathrm{f}} \pm 0.12$ & $0.44^{\mathrm{d}} \pm 0.01$ \\
\hline $\begin{array}{l}\text { W1 (without } \\
\text { PMPR) }\end{array}$ & $19.57^{\text {bcd }} \pm 0.94$ & $37.65^{\mathrm{h}} \pm 1.23$ & $238.22^{\mathrm{g}} \pm 0.96$ & $42.17^{\mathrm{h}} \pm 3.55$ & $19.26^{\mathrm{g}} \pm 0.12$ & $0.37^{\mathrm{d}} \pm 0.01$ \\
\hline $\begin{array}{l}\text { W2 (with } \\
\text { PMRP) }\end{array}$ & $21.35^{\mathrm{a}} \pm 0.36$ & $104.73^{\mathrm{e}} \pm 1.89$ & $382.67^{\mathrm{a}} \pm 1.67$ & $71.63^{\mathrm{e}} \pm 2.33$ & $66.19^{\mathrm{d}} \pm 0.17$ & $1.28^{\mathrm{c}} \pm 0.02$ \\
\hline $\begin{array}{l}\text { W2 (without } \\
\text { PMPR) }\end{array}$ & $20.28^{\mathrm{ab}} \pm 0.71$ & $74.69^{f} \pm 1.23$ & $257.67^{\mathrm{f}} \pm 2.89$ & $64.65^{\mathrm{f}} \pm 2.35$ & $45.52^{\mathrm{e}} \pm 0.23$ & $0.97^{\mathrm{c}} \pm 0.01$ \\
\hline $\begin{array}{l}\text { W3 (with } \\
\text { PMPR ) }\end{array}$ & $19.10^{\mathrm{cde}} \pm 0.21$ & $239.71^{\mathrm{a}} \pm 2.57$ & $372.67^{\mathrm{b}} \pm 1.67$ & $157.67^{\mathrm{a}} \pm 2.33$ & $95.99^{\mathrm{a}} \pm 0.06$ & $3.57^{\mathrm{a}} \pm 0.05$ \\
\hline $\begin{array}{l}\text { W3 (without } \\
\text { PMPR) }\end{array}$ & $16.84^{\mathrm{f}} \pm 0.54$ & $203.91^{\mathrm{c}} \pm 1.89$ & $317.67^{\mathrm{d}} \pm 3.33$ & $132.87^{b} \pm 3.55$ & $95.78^{a} \pm 0.06$ & $3.19^{\mathrm{a}} \pm 0.03$ \\
\hline $\begin{array}{l}\text { W4 (with } \\
\text { PMPR ) }\end{array}$ & $19.81^{b c} \pm 0.54$ & $209.26^{\mathrm{b}} \pm 1.23$ & $372.11^{\mathrm{b}} \pm 1.92$ & $84.81^{c} \pm 3.55$ & $87.95^{\mathrm{b}} \pm 0.23$ & $2.14^{b} \pm 0.05$ \\
\hline $\begin{array}{l}\text { W4 (without } \\
\text { PMPR) }\end{array}$ & $19.93^{\mathrm{de}} \pm 0.36$ & $129.84^{\mathrm{d}} \pm 1.89$ & $338.22^{c} \pm 2.55$ & $77.05^{\mathrm{d}} \pm 1.34$ & $74.02^{c} \pm 0.12$ & $1.21^{\mathrm{c}} \pm 1.01$ \\
\hline W5 & $18.51^{\mathrm{g}} \pm 0.71$ & $27.78^{\mathrm{i}} \pm 1.23$ & $196.00^{\mathrm{h}} \pm 1.67$ & $34.42^{\mathrm{i}} \pm 2.33$ & $15.80^{\mathrm{h}} \pm 0.45$ & $0.35^{\mathrm{d}} \pm 0.13$ \\
\hline Italian red wine & $2.85 \pm 0.71$ & $332.72 \pm 1.23$ & $376.56 \pm 3.47$ & $41.4 \pm 2.33$ & $87.23 \pm 0.23$ & $3.43 \pm 0.04$ \\
\hline Grape extract ${ }^{\mathrm{C}}$ & $0.71 \pm 0.36$ & $5.97 \pm 1.43$ & $201.00 \pm 0.00$ & $55.35 \pm 0.00$ & $2.02 \pm 0.23$ & $0.01 \pm 0.00$ \\
\hline
\end{tabular}

\footnotetext{
* Mean of 3 replication data within a column with different letters are significantly different $(\mathrm{P}<0.05)$.

${ }^{\mathrm{A}}$ Anti-acetylcholinesterase activity was analyzed at 1:10,000 dilution of the beverage sample. ${ }^{\mathrm{B}} \mathrm{PMPR}$ is "pieces of medicinal plant residue." ${ }^{\mathrm{C}}$ Results for grape extract analysis were expressed as $\mathrm{mg} / \mathrm{g}$ fresh grape extract.
}

\section{Acetylcholinesterase inhibitory activity}

In this study, the anti-acetylcholinesterase activities of all beverage samples at 1: 10,000 dilution were analyzed; otherwise, the absorbances of undiluted samples at $412 \mathrm{~nm}$ were too high and could not be measured. The beverage with mixed medicinal plants had a higher percentage of acetylcholinesterase inhibition, compared to the grape (B5) beverage (Table 3). This acetylcholinesterase inhibitory activity in the beverages may come from the combination of this activity in each plant. This indicated the synergistic effect of the active compounds in all the 
plants used as ingredients. Among all non-alcoholic beverages, the beverages B3 and B4 showed the highest percentage of acetylcholinesterase inhibition $(22.78 \%$ and $22.54 \%$ at 1:10,000 dilution, respectively). However, the beverage W2, (an alcoholic beverage fermented with PMPR) showed stronger acetylcholinesterase inhibition (21.35\% at 1:10,000 dilution) as compared to other alcoholic beverage formulations. Italian grape wine had a lower percentage of acetylcholinesterase inhibition (2.85\% at 1:10,000 dilution), compared to all beverages produced. Grape extract displayed low acetylcholinesterase inhibition $(0.71 \%$ at $1 \mathrm{mg} / \mathrm{mL}$ concentration). The anti-acetylcholinesterase activity of the positive control, galantamine, was $48.52 \pm 1.14 \%$ and $35.82 \pm 0.21 \%$ at 1 and $0.1 \mathrm{mg} / \mathrm{mL}$ concentration, respectively. The $\alpha$-tocopherol at 1 $\mathrm{mg} / \mathrm{mL}$ had an anti-acetylcholinesterase activity of $18.62 \pm 0.74 \%$.

\section{DISCUSSION}

In the current study, grape was one of the ingredients which possessed antioxidant activity. The antioxidant activity of the non-alcoholic beverage B5 (grape beverage) and alcoholic beverage W5 (grape alcoholic beverage) confirmed that one of the antioxidant sources in alcoholic beverages W1-W4 was grape. Their antioxidant activity may relate to their high phenolics and flavonoids. Santos et al. [30] reported that the methanolic skin extract of grape cultivated in Brazil (V. vinifera), Betanika (V. vinifera), Isabel (Vitis labrusca) and Niagara (V. labrusca) had total phenolics in the range of 1.43-2.46 mg GAE/g extract. The grape pulp extract of the same cultivar had a varying amount of total phenolics, (0.04-0.11 mg GAE/g extract), while resveratrol was detected in peels ( 1.17 to $12.96 \mu \mathrm{g} / \mathrm{g}$ extract) and seeds (2.03 to $2.44 \mu \mathrm{g} / \mathrm{g}$ extract). Terrier et al. [13] stated that anthocyanins, flavonols and dihydroflavonols are compounds in the member of flavonoids found in grapes. Flavanols in grape are called flavan 3ols. The majority of flavan 3-ols monomer found in grapes are (+)-catechin, and its isomer, ( -)epicatechin, while the minority of flavan 3-ols monomer found in grapes are gallic ester of (-)epicatechin and (-)-epicatechin 3-gallate. Zhu et al. [31] revealed that the skin of grapes ( $V$. vinifera) in East Asia and North America contained varying amount of flavonoids (67.08$1,892.53 \mathrm{mg}$ QE/g dry weight) among the different cultivars.

Strong antioxidant activity of the mixed medicinal plant containing beverages (the beverages B2, B3 and B4) may result from synergistic effects of many phytochemicals in different plants used as the ingredients, such as grapes, gambir (U. gambir), Indian gooseberry ( $P$. emblica) fruits, myrabolan wood (T. chebula) fruits, white lotus petals and other plants. This synergism is often demonstrated by the antioxidant activity of the mixture, which is greater than the sum of the antioxidant activity of the single active compound molecule [4]. Myrabolan wood fruits, Indian gooseberry fruits, and gambir extracts were reported to possess very strong antioxidant activity with the $\mathrm{EC}_{50}$ of $387.23,490.47$ and $478.71 \mu \mathrm{g}$ extract/mg DPPH by DPPH radical scavenging assay [17]. Anggraini et al. [19] also revealed strong antioxidant activity of gambir extracts. They found that the major active compounds in gambir extracts were catechin, epicatechin and caffeic acid. Their antioxidant activities were found to relate to their catechin contents. Pfundstein et al. [18] reported that the predominant class of polyphenols detected in $T$. chebula fruit extract was the chebulic ellagitannins, while other compounds present in decreasing order were chebulagic acid, methyl neochebulinate, chebulic acid, chebulanin and methyl neochebulagate. Fruits of Indian gooseberry are rich in vitamin C, total phenolics and flavonoids, 
and had strong antioxidant activity. Mayachiew and Devahastin [16] revealed that P. emblica fruit extract contained a high amount of phenolic compounds (290 mg/g extract) and ascorbic acid (11.21\%). Maisuthisakul et al. [15] reported that the ethanolic extract of Indian gooseberry fruits had strong antioxidant activity with 2.0 antiradical activity by DPPH method, and had total phenolics of $69.1 \mathrm{mg}$ GAE. It also had total flavonoids of $23.1 \mathrm{mg}$ rutin equivalents per gram dried weight of plant. Moreover, this plant extract contained $12.3 \mathrm{~g}$ dietary fiber, $111.1 \mathrm{~g}$ calcium, $3.1 \mathrm{mg}$ iron, $636 \mathrm{mg}$ vitamin $\mathrm{C}$ per $100 \mathrm{~g}$ edible portion, dry weight basis.

Strong anti-acetylcholinesterase activity found in the beverages B3, B4 and W2 was probably due to the synergistic effects of the plants with high anti-acetylcholinesterase activity, such as grapes, black galingale rhizomes, sacred lotus petals, serpentine roots, whole plant of asiatic pennywort, saffron pollens, gingko leaves and blue pea flowers. The presence of resverastrol in grapes, (which has been found to possess neuroprotective effect in mice) [32], crocin in saffron, (which has been demonstrated to improve impairment of learning behavior in mice), and bornyl acetate, $\alpha$-pinene, $\beta$-pinene and $\gamma$-terpinene in essential oil of asiatic penneywort (C. asiatica), (which are known to inhibit acetylcholinesterase) [20] may have been responsible for this activity. Resveratrol (3, 5, 4'-trihydroxystibene) is a stilbene compound acting as phytoalexins. This compound was synthesized when plants are attacked by pathogens [33]. Moreover, crude methanolic extracts of black galingale rhizomes, sacred lotus petals, serpentine roots and asiatic pennywort leaves at $1 \mathrm{mg} / \mathrm{mL}$ were reported to possess strong acetylcholinesterase inhibitory activity (more than $70 \%$ inhibition), whereas the extracts of gingko (G. biloba) leaves, saffron pollens and blue pea flowers at $1 \mathrm{mg} / \mathrm{mL}$ were found to exhibit $32.73,29.21$ and $25.55 \%$ acetylcholinesterase inhibition, respectively [17]. Ingkaninan et al. [34] reported that methanolic extract of sacred lotus stamen had $23.77 \%$ acetylcholinesterase inhibitory activity. Some compounds, such as flavonoids including kaempferol and its glycosides, and isorhamnetin glycosides, and some non-flavonoids (adenine, myo-inositol, arbutin and $\beta$-sitosterol glucopyranoside) have been isolated from sacred lotus stamen [35]. In addition, gingko, asiatic pennywort ( $C$. asiatica) and saffron have been used traditionally to improve memory loss and have been evaluated for their effects on cognitive function [20]. Takuma et al. [36] revealed that treatment with G. biloba extract (EGb 761) improved memory impairment and neuronal loss of hippocampus in female rats, while Rao et al. [37] reported that treatment with aqueous extract of the $C$. asiatica whole plant during postnatal developmental stage provided beneficial effects on cognitive function in mice. Alcoholic extracts of stems, flowers, leaves and fruits of blue pea (C. ternatea) were found to be sedative in mice [38].

The violet color in the beverages B2-B4 and W2-W4 were probably due to the color pigments in blue pea flowers and grape skin. Ternatins are blue anthocyanins in the petals of $C$. ternatea flowers. They are acylated anthocyanins based on delphinidin. Ternatins (blue anthocyanins) and three flavanol glycosides (kaempferol, quercetin and myricetin) have been isolated from the petals of C. ternatea [39]. Anthocyanins are also found in grape skin. Grape skin and wine made from $V$. Vinifera species were reported to contain 3-O-acylated monoglucosides of five major anthocyanins, which are delphinidin, cyanidin, petunidin, peonidin and malvidin [40]. The anthocyanins are orange red at low $\mathrm{pH}(\mathrm{pH}<7.0)$, violet at neutral $\mathrm{pH}$ $(\mathrm{pH} 7.0)$, and dark blue at high $\mathrm{pH}(\mathrm{pH}>7.0)$ [40]. The violet or blue color in the alcoholic beverages were probably due to the color of anthocyanins at the low $\mathrm{pH}$ of the beverages $(\mathrm{pH}$ 
3.58-3.93, Table 2) mixed with the color of other ingredients, such as blue pea flowers. In addition, alcoholic beverages fermented with PMPR had lower brightness, and higher redness and blueness. This was probably because more compounds from grape and PMPR were extracted during fermentation. Some researchers have reported that the amount of anthocyanins increased to the highest level at the beginning stage of red wine fermentation, while tannin extraction occurred continuously during fermentation [13].

\section{CONCLUSIONS}

The beverages B3, W2 and W3 with mixed medicinal plants could become valuable sources of natural antioxidants and acetylcholinesterase inhibitors. These new beverages were rich in bioactive phenolics, flavonoids and tannins with strong antioxidant and anti-acetylcholinesterase activities. Thus, there is the possibility that these beverages could provide health-promoting benefits when consumed by protecting against Alzheimer's disease and other oxidative stress relates diseases.

Abbreviations: Alzheimer's disease (AD), pieces of medicinal plant residue (PMPR), 2,2diphenyl-1-picrylhydrazyl (DPPH), ferric reducing antioxidant power (FRAP), acetylcholine iodide (ATCI), 5, 5'-dithio-bis (2-nitrobenzoic acid) (DTNB)

Competing interests: The authors declare that there were no competing interests.

Authors' Information: Suree Nanasombat, PhD (Food Science) is the advisor for this project, giving advice for the research protocols and helping for interpretation of data and writing this manuscript. Jidapa Thonglong is a graduated student who performed all the lab work and statistical analysis of the data. Jutharat Jitlakha is a graduated student who performed all lab work and statistical analysis of the data.

Acknowledgements and Funding: This study was supported by the Faculty of Science, KMITL research grant. The authors would like to thank the Faculty of Science, King Mongkut's Institute of Technology Ladkrabang, Thailand, for financial support of this research project.

\section{REFERENCES}

1. Surrey K: Functional food, beverage market increase worldwide. [http:// www.naturalproductsinsider.com/news/2014/11/functional-food-market-increaseworldwi.aspx]

2. Bonar A: Functional foods market is expected to grow by $25 \%$ by 2017 : Leatherhead. [http://www.navigator.com/Market-Trends/Functional-foods-market-is-expected-togrow-25-by-2017-Leatherhead]

3. Wootton-Beard PC, Ryan L: Improving public health?: The role of antioxidant-rich fruit and vegetable beverages. Food Res Int 2011, 44:3135-3148. 
4. Blasa M, Gennari L, Angelino D, Ninfali P: Fruit and vegetable antioxidants in health. In Bioactive Foods in Promoting Health: Fruits and Vegetables. Edited by Watson RR, Preedy VR. New York: Elsevier Inc; 2010:37-58.

5. Saeidnia S, Abdollahi M: Toxicological and pharmacological concerns on oxidative stress and related diseases. Toxicol Appl Pharmacol 2013, 273:442-455.

6. Mukherjee PK, Kumar V, Mal M, Houghton PJ: Acetylcholinesterase inhibitors from plants. Phytomedicine 2007, 14:289-300.

7. Heinrich M, Teoh, HL: Galantamine from snowdrop-the development of a modern drug against Alzheimer's disease from local Caucasian knowledge. J Ethnopharmacol 2004, 92:147-162.

8. Swerdlow RH: Brain aging, Alzheimer's disease, and mitochondria. Biochim Biophys Acta 2011, 1812:1630-1639.

9. Silva T, Reis J, Teixeira J, Borges F: Alzheimer's disease, enzyme targets and drug discovery struggles: From natural products to drug prototypes. Ageing Res Rev 2014, 15:116-145.

10. Krall WJ, Sramek JJ, Cutler NR: Cholinesterase inhibitors: a therapeutic strategy for Alzheimer's disease. Ann Pharmacother 1999, 33:441-450.

11. Schulz V: Ginkgo extract or cholinesterase inhibitors in patients with dementia: What clinical trials and guidelines fail to consider. Phytomedicine 2003, 10:74-79.

12. Choi D-Y, Lee Y-J, Hong JT, Lee H-J: Antioxidant properties of natural polyphenols and their therapeutic potentials for Alzheimer's disease. Brain Res Bull 2012, 87:144153.

13. Terrier N, Poncet-Legrang C, Cheynier V: Anthocyanins and anthocyanin-derived compounds. In Wine Chemistry and Biotechnology. Edited by Moreno-Arribas MV, Polo MC. New York: Springer Science Business Media LLC; 2009:464-476.

14. Fernández-Mar MI, Mateos R, García-Parrilla MC, Puertas B, Cantos-Villar E: Bioactive compounds in wine: resveratrol, hydroxytyrosol and melatonin: a review. Food Chem 2012, 130:797-813.

15. Maisuthisakul P, Pasuk S, Ritthiruangdej P: Relationship between antioxidant properties and chemical composition of some Thai plants. J Food Comp Anal 2008, 21:229-240.

16. Mayachiew P, Devahastin S: Antimicrobial and antioxidant activities of Indian gooseberry and galangal extracts. LWT-Food Sci Technol 2008, 41:1153-1159.

17. Nanasombat S, Bubpasawa T, Tamaput N, Srimakhan Y: Antimicrobial activity of Thai medicinal plants against beverage spoilage microorganisms and their potential in retarding Alzheimer's disease progression. Pharmacog Com 2014, 4 (3):77-87.

18. Pfundstein B, El Desouky SK, Hull WE, Haubner R, Erben G, Owen RW: Polyphenolic compounds in the fruits of Egyptian medicinal plants (Terminalia bellerica, Terminalia chebula and Terminalia horrida): characterization, quantitation and determination of antioxidant capacities. Phytomedicine 2010, 71:1132-1148.

19. Anggraini T, Tai A, Yoshino T, Itani T: Antioxidative activity and catechin content of four kinds of Uncaria gambir extracts from West Sumatra, Indonesia. Afr J Biochem Res 2011, 5:33-38. 
20. Howes M-JR, Perry NSL, Houghton PJ: Plants with traditional uses and activities, relevant to the management of Alzheimer's disease and other cognitive disorders. Phytother Res 2003 17: 1-18.

21. AOAC: Official Method of Analysis of AOAC International. The Association of Official Analytical Chemists: Gartherburg, Maryland; 2005.

22. Orak HH: Total antioxidant activity, phenolics, anthocyanins, polyphenoloxidase activities of selected red grape cultivars and their correlations. Sci Hortic 2007, 111:235241.

23. Costa ASG, Nunes MA, Almeida IMC, Carvalho MR, Barroso MF, Alves RC, Oliveira MBPP: Teas, dietary supplements and fruit juices: a comparative study regarding antioxidant activity and bioactive compounds. LWT-Food Sci Technol 2012, 49:324328.

24. Martins AC, Bukman L, Vargas AMM, Barizão ÉO, Moraes JCG, Visentainer JV, Almeida VC: The antioxidant activity of teas measured by the FRAP method adapted to the FIA system: optimizing the conditions using the response surface methodology. Food Chem 2013, 138:574-580

25. Ellman GL, Courtney KD, Andres jr. V, Featherstone RM: A new rapid colorimetric determination of acetylcholinesterase activity. Biochem Pharmacol. 1961, 7:88-95.

26. Sancheti S, Sancheti S, Um B-H, Seo S-Y: 1,2,3,4,6-penta-O-galloyl- $\beta$-D-glucose: A cholinesterase inhibitor from Terminalia chebula. S Afr J Bot 2010, 76:285-288.

27. Singleton VL, Orthofer R, Lamuela-Raventor RM: Analysis of total phenols and other oxidation substrates and antioxidants by means of folin-ciocateu reagent. Method Enzymol 1999, 299:152-178.

28. Yang J, Martinson TE, Liu RH: Phytochemical profiles and antioxidant activity of wine grape. Food Chem 2009, 116:332-339.

29. Kathirvel A, Sujatha V: In vitro assessment of antioxidant and antibacterial properties of Terminalia chebula Retz. Leaves. Asian Pac Journal Tropical Biomed 2012, 2:S788S795.

30. Santos LP, Morais DR, Souza NE, Cottica SM, Boroski M, Visentainer JV: Phenolic compounds and fatty acids in different parts of Vitis labrusca and V. vinifera grape. Food Res Int 2011, 44:1414-1418.

31. Zhu L, Zhang Y, Lu J: Phenolic contents and compositions in skins of red wine grape cultivars among various genetic backgrounds and originations. Int J Mol Sci 2012, 13:3492-3510.

32. Anekonda TS: Resveratrol-a boon for treating Alzheimer's disease? Brain Res Rev 2006, 52:316-326.

33. Chun-Fu W, Jing-Yu Y, Fang W, Xiao-Xiao W: Resveratrol: botanical origin, pharmacological activity and applications. Chinese J Nat Med 2013, 11:1-15.

34. Ingkaninan K, Temkitthawon P, Chuenchom K, Yuyaem T, Thongnoi W: Screening for acetylcholinesterase inhibitory activity in plants used in Thai traditional rejuvenating and neurotonic remedies. J Ethnopharmacol 2003, 89:261-264.

35. Mukherjee PK, Mukherjee D, Maji AK, Rai S, Heinrich M: The sacred lotus (Nelumbo nucifera) -phytochemical and therapeutic profile. J Pharm Pharmacol 2009, 61:407-422. 
36. Takuma K, Hoshina Y, Arai S, Himeno Y, Matsuo A, Funatsu Y, Kitahara Y, Ibi D, Hayase M, Kamei H, Mizoguchi H, Nagai T, Koike K, Inoue M, Yamada K: Ginkgo biloba extract 761 attenuates hippocampal neuronal loss and cognitive dysfunction resulting from chronic restraint stress in ovariectomized rats. Neuroscience 2007; 149:256-262.

37. Rao SB, Chetana M, Devi PU: Centella asiatica treatment during postnatal period enhances learning and memory in mice. Physiol Behav 2005, 86:449-457.

38. Kulkarni C, Pattanshetty JR, Amruthraj G: Effect of alcoholic extract of Clitoria ternatea Linn. on central nervous system in rodents. Indian J Exp Biol 1988, 26:957960.

39. Mukherjee PK, Kumar V, Kumar NS, Heinrich M: The Ayurvedic medicine Clitoria ternatea-from traditional use to scientific assessment. J Ethnopharmacol 2008, 120:291301.

40. Monagas M, Bartolomé B: Anthocyanins and anthocyanin-derived compounds. In Wine Chemistry and Biotechnology. Edited by Moreno-Arribas MV, Polo MC. New York: Springer Science Business Media LLC; 2009:439-456. 